\title{
What Drives Online Shopping Among Tertiary Students in Ghana: The Role of Attitude And Subjective Norm
}

\author{
${ }^{1}$ Samuel Antwi, ${ }^{2}$ Moses Agyemang Ameyaw, ${ }^{3}$ Mateyenu Moferi Adamu \\ ${ }^{I}$ School of Management and E-Business, Zhejiang Gongshang University, Hangzhou 310018, China, \\ samantwi88@outlook.com \\ ${ }^{2}$ School of Business Administration, Zhejiang Gongshang University, Hangzhou 310018, China, \\ mosesameyaw1@gmail.com \\ ${ }^{3}$ Centre for Entrepreneurship and Small Enterprise Development, University of Cape Coast, Cape Coast, CC192, Ghana, \\ ammoferi@gmail.com
}

\begin{tabular}{l} 
ABSTRACT \\
\begin{tabular}{|l|} 
Key Words: Consumers' \\
Attitude, Subjective \\
norm, Purchase \\
Intention, Online \\
Reviews, \\
Recommendation, and \\
Perceived Risk
\end{tabular} \\
\hline
\end{tabular}

This study aims to give a comprehensive insight into the drive of online shopping among tertiary students in Ghana, considering the role of attitude and subjective norm. With the technique of convenience sampling, the data were gathered from Ghanaian tertiary students via a web survey. In all, the selfadministrated questionnaire consisted of 400 respondents. In analyzing the data, SmartPLS version 3.2.9 was used. The findings revealed that recommendations have a significant positive effect on purchase intention, attitude, and subjective norms. Also, it was realized that there is a significant positive effect of online reviews on purchase intention, attitude, and subjective norm. Lastly, though there was no significant influence of attitude on purchase intention, subjective norms positively influenced purchase intention. In all, these findings show that a favorable online review and recommendations by an earlier user will eventually trigger a positive purchase intention, among others. The results are valuable to the growth and expansion of online shops. It admonishes that being able to meet early online consumers' needs and giving attention to their feedback is very instrumental in attracting other consumers.

\section{Introduction}

E-commerce or online shopping gained its freedom in the 1990s when Amazon, eBay, and Alibaba were established after the Internet was opened for commercial use. Since then, it has gained massive popularity as more people continue to shop online. While many industries, including the aviation industry, tourism industry, and some other industries, were significantly affected by the Covid19 pandemic, e-commerce or online shopping became more indispensable than ever. More people had to stay home, and some businesses were closed down, so people had to resort to shopping online. Besides, most countries, including Ghana, institutionalized a nationwide or some regional lockdown. Business Insider (2015) anticipated that any global crisis could trigger businesses to adopt online selling. According to Sengretsi (2020), the first-ever e-commerce website in Ghana, "eshopafrica.com" was launched in 2001, although Cordelia Salter-Nour founded the company in 1999. The website sold locally manufactured products (made in Ghana products) to online consumers.

The history of e-commerce in Ghana cannot be complete without past players in the industry like shopafrica53.com, afrochiconline.com, africaretail.com, tisu.com.gh, ahonya.com, and mogoogi.com. Some primary e-commerce website in Ghana presently includes jumia.com.gh, superprice.com, kikuu.com.gh melcomonline.com, zoobashop.com. Other cross-border e-commerce platforms like Amazon, Alibaba, eBay, Wish, among others, do sell products to the Ghana market. Ghana is one of the fastest-growing countries in SubSaharan Africa in terms of information technology. The country became one of the first African 
countries to liberalize its telecommunications market, having had its first telecommunication network in 1992 and subsequently connecting to the World Wide Web in 1994 (Endert 2018). Later, the country became the next African country to access full internet connectivity in Sub-Saharan Africa in August 1995 (Tevie et al., 2016). Individuals using the Internet in Ghana rose from $0.154 \%$ in 2000 to $37.884 \%$, according to (World Bank Report 2018). Separate data from Kemp (2020) indicates that Ghana's internet penetration stood at $48 \%$ as of January 2020, a $7.5 \%$ increment from the previous year. The report further indicates that the total number of social media users was 6 million, a 12\% increment between April 2019 and January 2020.

Undoubtedly, the majority of the social media usage and internet usage in Ghana are the younger generations. This is in line with Ofori and AppiahNimo (2019). They opined that the youth, especially those in the tertiary institutions, are exposed to technology and subsequently make regular use of the Internet in their daily activities. Consequently, they are likely to accept online shopping as compared to the older generation. To Deneen and $\mathrm{Yu}$ (2018), online shopping saves students time and energy because they can shop anytime and anywhere. This has been made possible because of internet connectivity and an online shopping platform. Although the process of shopping online appears to be simple and more convenient than the traditional shopping method, there are a lot of considerations that an online consumer (tertiary students) considers before arriving at a final purchasing decision. These considerations may take a few hours, days, or even more before a final purchasing decision can be reached. These may include perceived usefulness of online reviews, trust, reputation, perceived ease of use, satisfaction, perceived risk, and privacy (Ansary 2013; Mintah 2018; Oghazi et al. 2020; Olusoji et al. 2015; Singh et al. 2016; Ventre \& Kolbe 2020).

Other considerations may entail subjective norm, perceived usefulness, perceived behavioral control, personal attitude, health consciousness, perceived enjoyment, perceived cost (Gidey 2017; Lee et al. 2020; Lim et al. 2016; Ofori \& Appiah-Nimo 2019; Wang et al. 2019), etc. In Ghana, the tertiary education system is cosmopolitan in nature. Thus, students from different parts of the country meet together on a school campus to learn. In their course of study, they interact and share information among themselves, which exposes them to another knowing that they may not know. Despite the sufficient literature on the factors that influence customers to shop in an online shopping platform, limited research has been conducted in Ghana to find the determinants of online shopping among tertiary education students. The only work obtained in Ghana on the determinant of online shopping among tertiary education students was Ofori and AppiahNimo (2019). The researchers used perceived usefulness, perceived ease of use, perceived risk, and perceived cost as online shopping determinants.

Given the academic and practical need to expand the research and the debate on the factors that influence Ghanaian tertiary education students' purchase intention in an online shopping platform, the study used online reviews, recommendations, and perceived risk as determinants with information prorider The reminder of the research is as follows. The next section presents the literature review and hypothesis of the study. This is followed by the Methodology, where the measurement items and data collection are discussed. After that, the data analysis and main results are presented. Finally, the research ends with discussing the main findings, implications for theory and practice, and the suggestions for future study.

\subsection{Literature Review and Hypothesis Development}

\subsection{Recommendations}

According to Liang et al. (2011), early consumers have the zeal to share their online shopping experiences with others who may need it. The students in tertiary institutions in Ghana are mostly exposed to technology and hence make regular use 
of the Internet Ofori and Appiah-Nimo (2019). Such students buy products online and share their shopping experiences with their peers who may need the product. This is in line with Marsden (2009), who posited that online consumers have the zeal to share their friends' shopping details. Besides, most online consumers prefer to buy recommended products (Marsden 2009) because they trust their friends to provide them credible information on a product than the online retailer (Kelly et al. 2010). Previous researches (Bai et al. 2015; Di Maria \& Finotto 2008; Riemer \& Lehrke 2009) have claimed that products recommended by early consumers who have prior history or experience of a particular product have a significant influence on purchasing intention. In addition to this, the research seeks to find the relationship between recommendations and attitude and subjective norms. Some tertiary may be willing to buy a product recommended by their peers without hesitation because it fits their philosophies. On the contrary, some students may have to evaluate the information shared by their peers before making a decision. Therefore, the following hypotheses are proposed;

H1a: There is a significant positive relationship between recommendations and purchase intention

H1b: There is a significant positive relationship between recommendations and attitude

H1c: There is a significant positive relationship between recommendations and subjective norm

\subsection{Online Reviews}

Most e-commerce or online shopping platforms provides opportunities for early consumers to give reviews on their purchases. Thus, online or product reviews are posted by consumers (Chen et al. 2011) who rate the products based on their experience (Wang and Hajli, 2015). This implies that online reviews are subjective and dependent on how they evaluate the product purchased and the transaction process. Davidson and Copulsky (2006) reported that product reviews tend to affect a brand reputation. A favorable online rating has the propensity to increase the revenue of an online retailer (Heinonen 2011). This is because product reviews provide vital information to new consumers about the products they intend to purchase. The information obtained via the online reviews aids new consumers to arrive at a final purchasing decision (Islam et al., 2017). The research will also ascertain the relationship between online reviews and an online consumer attitude and subjective norms. An online consumer's attitudes focus on their opinions on certain behaviors, whereas the subjective norms focus on external influences from their peers. Therefore, we propose that;

H2a: There is a significant positive relationship between online reviews and purchase intention

H2b: There is a significant positive relationship between online reviews and attitude

H2c: There is a significant positive relationship between online reviews and subjective norm

\subsection{Perceived Risk}

Perceived risk measures the uncertainties associated with an online transaction (March 1978) and how its outcome cannot be controlled (Vlek and Stallen 1980). It is the degree to which an online consumer expresses uncertainty about a product offering (Dai et al. 2014), and such uncertainties are subjective in nature. The outcome is based on an individual expectation, and it varies from one person to another. As such, Malaquias and Hwang (2016) consider it the main barrier to the growth of e-commerce, which needs serious attention. The online shopping platform involves uncertainty because there is no face-to-face interaction, and an online consumer does not physically see the product he intends to purchase. In support of this, Tamatompol et al. (2017) claimed that perceived risk is mostly higher in online transactions than offline transactions because of online transactions' nature. The result is that most Ghana consumers are reluctant to shop online, especially when it involves a considerable 
sum of money, and prefer to use the traditional shopping method despite the advancement of technology in recent years. Forsythe et al. (2006) divide perceived risk into three elements; financial risk, product, and delivery risk. When tertiary students in Ghana order an effect on an online shopping platform, they make payments either through mobile or electronic payment. The risk at this stage is their privacy and security of their payment information. Besides, they do not have the opportunity to examine the product before making payment physically. Also, a possible failure or delay in the shipment of the goods cannot be overlooked.

The research also aims to determine if there is a relationship between perceived risk and an individual attitude to a behavior. Also, it seeks to find out the relationship between perceived risk and subjective norms. Many researchers (Kim \& Park 2013; Kumar 2018; Rahman \& Sloan 2017; Singh \& Srivastava 2018) have found that perceived risk affects online shopping. Hence it is hypothesized;

H3a: There is a significant positive relationship between perceived risk and purchase intention

H3b: There is a significant positive relationship between perceived risk and attitude

H3c: There is a significant positive relationship between perceived risk and subjective norm

\subsection{Attitudes}

Amaro and Duarte (2015) define attitude towards as the strength of a personal feeling towards purchasing a product. According to the researchers, such feelings may be favorable or unfavorable and may be based on the consumer's unique personal values and philosophies. Thus, tertiary students' acceptance of online shopping may be based on their personal values due to the things they were exposed to when growing up. For example, students exposed to technological and electronic gadgets are likely to readily accept e-commerce than those who were not exposed to such things when growing up. Fishbein and Ajzen (1975) said that a positive attitude toward the information results in a higher intention in executing a particular action. An individual attitude results from the evaluation, which may be favorable or unfavorable, all the expected outcomes of a specific behavior. In online shopping, an individual positive attitude will lead to a higher intention of shopping online. Various studies have shown a relationship between an individual attitude and their purchasing intention in an online shopping platform (da Chen et al. 2002; Da Chen \& Tan 2004; Lee et al. 2006; O'Cass \& Fenech 2003; Vijayasarathy, 2004). Therefore, we hypothesized that;

H4: There is a significant positive relationship between attitude and purchase intention

\subsection{Subjective Norms}

Subjective norms denote how people react to information shared with them by others (Ajzen, 1991). Thus, the reaction exhibited by a tertiary student when his or her colleagues or mates who they count on or can rely on provides feedback or recommends a product for them to purchase. Subjective norms, according to Lee et al. (2020), are related to social norms thus, whether a practice or behavior is in line with the philosophy and culture of the one receiving the information. The social settings in which an individual finds him or herself are vital sources of information that help reduce any doubt and determine acceptable behaviors based on the rules and philosophy of their environment. Various studies have shown that an individual attitude influences their online purchasing intention. Literature obtained revealed that subjective norms would influence tertiary students in Ghana's online purchasing intention. Jamil and Mat (2011) found out that subjective standard tends to affect purchase intention. Other studies such as (Al-Jabari et al. 2012; Jamil and Mat 2011; Leeraphong and Mardjo, 2013; Xie et al. 2011) all had a similar conclusion that subjective norm has a significant direct influence on a customer purchase intention in an online shopping platform. Hence, we proposed that; 
H5: There is a significant positive relationship between subjective norm and purchase intention

H6b: Subjective norms positively mediates the relationship between online reviews, recommendations and referrals and perceived risk and purchase intention.

\subsection{The Mediating Role of Attitude and Subjective Norm}

The research will also determine if consumer attitudes and their subjective norms mediate the relationship between the online shopping determinants among tertiary education students in Ghana. This is because some authors including (Kashif et al. 2018; Yakasai and Jusoh 2015), asserted that the importance of attitude in a behavioral intention could not be overlooked. Amaro and Duarte (2015) and Singh and Srivastava (2018) also report that subjective norms focus on examining intention. Besides, less work has been done on online purchase intention using attitudes and subjective norms as a mediator. Hence, we propose that;

H6a: Attitudes positively mediates the relationship between online reviews, recommendations and referrals and perceived risk and purchase intention.

H6b: Subjective norms positively mediates the relationship between online reviews, recommendations and referrals and perceived risk and purchase intention.

\subsection{Purchase Intention}

The intention to purchase online measures the probability that an individual would perform an online transaction in the future (Wu et al., 2011). The definition implies a purchase intention is a process and may take a minute, hours, or days before an individual arrives at a final purchasing decision. Thus, a purchase intention may not turn into actual purchase. Consequently, Wagner Mainardes et al. (2019) also defined an online purchase intention as a predictive factor of consumer behavior towards an action or an activity to finalize a negotiation online. Such factors are several motivational factors than online consumer experiences (Diallo and Siqueira 2017) and differ from developed markets and emerging markets (Bianchi and Andrews 2012). Engel et al. (1995) claimed that factors such as motivation, changes in needs, desired alternatives, consumption circumstances, and new information could alter a customer's purchase intention. Any time an online consumer has a positive purchase intention, then there is a likelihood that it will turn into actual purchase intention.

\subsection{Methodology}

\subsection{Measurement Items}

In this research, a questionnaire was used to collect data from university students. The questionnaire was in two parts. The first part sought to collect data relating to their background information such as gender, age, shopping experience, and educational level. Section two of the research instrument solicited responses from the subjects concerning the research hypothesis formulated. Section two of the measurement items were measured using a sevenpoint Likert scale with one (1) representing Strongly Disagree and seven (7) representing Strongly Agree. The measurement items were in five constructs with the independent variables, having four measurement items each. The mediators were attitude and subjective norms. Each dimension had four measurement items. Similarly, the dependent variable, purchase intention, also had four measurement items. The questionnaire used for this study was adapted from previous studies, and modifications were then made to suit the context of this research. The questionnaire was adapted from previous studies such as (Bebber et al. 2017; Han and Windsor 2011; Jiménez-Castillo and SánchezFernández 2019; Lee et al. 2020; Pavlou 2003; Wang et al. 2019). To ensure that the questionnaire was devoid of any biases, errors, and others of a similar kind, it was first sent to 10 students (Doctoral and Masters) in e-commerce and an expert in e-commer- 
ce for scrutiny. The feedback received from them was used to draft a revised questionnaire.

\subsection{Data Collection}

The researchers employed an online survey to solicited data from university students in Ghana. The subjects were instructed to participate in the survey only if they do buy products online for personal use. This was to ensure that they do not respond to what they perceived it to be but instead based on their personal experience. A convenience sampling technique was used to select the subjects for the study. For the subjects to fill the online survey, the researchers employed Microsoft Forms as it is very familiar among university students in Ghana. A weblink that leads to the online survey and the study's purpose was sent to the students via WhatsApp Messenger, Email, and SMS. The subjects participated in the online survey voluntarily. At the end of it, a total of four hundred (400) responses were received.

\subsection{Data Analysis}

In this study, the researchers used a two-stage analytical procedure to assess the subjects' data with
SmartPLS version 3.2.9. The first procedure was on the measurement model, and the second was on the structural model. On top of this, the respondents' background data were analyzed using percentages and frequencies in Statistical Package for Social Sciences (SPSS) version 26.

\subsection{Demographic Information of Respondents}

Table 1 presents the descriptive measurement of the demographic information of the respondents. Among the sample pool of $n=400$ respondents, most were male $(57 \%)$, and the remaining (43\%) were females. In terms of age, the majority were from the age group of $20-25$ (42\%), followed by $26-$ $30(26.5 \%)$, above $30(16.8 \%)$, and below 20 $(15.3 \%)$. With regards to the online shopping experience, the majority of the respondents have had 1-3 years' experience (43.80\%), followed by $4-6$ years' experience $(22.5 \%)$, less than a year experience (16.8\%), 7-10 years' experience $(9.3 \%)$ and the rest of them had over ten years' experience (7.80\%) of online shopping. With regards to the level of education, more than half $(69 \%)$ of the respondents were pursuing a Diploma/Degree, followed by Masters (22.5\%), and the remaining respondents (8.5\%) were pursuing their PhDs.

Table 1. Descriptive Measurement of Demographic Variables $(\mathrm{N}=400)$

\begin{tabular}{llll}
\hline \hline Variables & Items & Frequency & $\mathbf{\%}$ \\
\hline Gender & Male & 228 & 57.00 \\
& Female & 172 & 43.00 \\
Age (years) & Below 20 & 61 & 15.30 \\
& $20-25$ & 168 & 42.00 \\
& $26-30$ & 106 & 26.50 \\
Online Shopping Experience (years) & Above 30 & 65 & 16.30 \\
& Below 1 & 67 & 16.80 \\
& $1-3$ & 175 & 43.80 \\
& $4-6$ & 90 & 22.50 \\
Level of Education & $7-10$ & 37 & 9.30 \\
& Above 10 & 31 & 7.80 \\
& Diploma/Degree & 276 & 69.00 \\
& Masters & 90 & 22.50 \\
\hline \hline
\end{tabular}

Note: $\mathrm{N}=$ Sample size and $\%=$ Percentage 


\section{Available at: www.imperialpublications.com}

\subsection{Measurement Model}

The validity and the reliability of the research instrument were assessed with the help of the SmartPLS version3.2.9. We followed the procedure suggested by Nunnally and Bernstein (1994) and Fornell and Larcker (1981) to examine the reliability. According to them, if both Cronbach's alpha and composite reliability are above 0.70 , the constructs' reliability can be confirmed. As shown in Table 2, the Cronbach's alpha and composite reliability for all constructs exceed 0.7 , meeting the suggested threshold. The items' convergent validity was assessed using the average variance extracted (AVE) and factor loadings. The average variance extracted AVE values should be more than the recommended level of 0.5 (Hair et al., 2006). As shown in Table 2, the average variance for all the constructs was above the recommended threshold of 0.5 . Table 2 revealed that the factor loadings for all the measurement items were significant and ranged from 0.776 to 0.939 .

Table 2: Confirmatory Factor Analysis (CFA)

\begin{tabular}{|c|c|c|c|c|c|}
\hline Factors/Items & Loadings & CR & AVE & $\alpha$ & Sig \\
\hline \multicolumn{6}{|c|}{ Recommendations } \\
\hline RE1 & 0.922 & \multirow{3}{*}{0.947} & \multirow{3}{*}{0.856} & \multirow{3}{*}{0.916} & \multirow{3}{*}{$* * *$} \\
\hline RE2 & 0.914 & & & & \\
\hline RE3 & 0.939 & & & & \\
\hline \multicolumn{6}{|l|}{ Online Reviews } \\
\hline OR1 & 0.776 & \multirow{4}{*}{0.923} & \multirow{4}{*}{0.750} & \multirow{4}{*}{0.888} & \multirow{4}{*}{$* * *$} \\
\hline OR2 & 0.883 & & & & \\
\hline OR3 & 0.888 & & & & \\
\hline OR4 & 0.912 & & & & \\
\hline \multicolumn{6}{|l|}{ Perceived Risk } \\
\hline PR1 & 0.873 & \multirow{4}{*}{0.932} & \multirow{4}{*}{0.775} & \multirow{4}{*}{0.903} & \multirow{4}{*}{ *** } \\
\hline PR2 & 0.873 & & & & \\
\hline PR3 & 0.899 & & & & \\
\hline PR4 & 0.878 & & & & \\
\hline \multicolumn{6}{|l|}{ Attitude } \\
\hline AT1 & 0.902 & \multirow{4}{*}{0.948} & \multirow{4}{*}{0.820} & \multirow{4}{*}{0.927} & \multirow{4}{*}{$* * *$} \\
\hline AT2 & 0.900 & & & & \\
\hline AT3 & 0.906 & & & & \\
\hline AT4 & 0.912 & & & & \\
\hline \multicolumn{6}{|c|}{ Subjective Norms } \\
\hline SN1 & 0.914 & \multirow{4}{*}{0.950} & \multirow{4}{*}{0.826} & \multirow{4}{*}{0.930} & \multirow{4}{*}{$* * *$} \\
\hline SN2 & 0.923 & & & & \\
\hline SN3 & 0.890 & & & & \\
\hline SN4 & 0.908 & & & & \\
\hline \multicolumn{6}{|c|}{ Purchase Intention } \\
\hline PI1 & 0.907 & \multirow{4}{*}{0.951} & \multirow{4}{*}{0.828} & \multirow{4}{*}{0.931} & \multirow{4}{*}{$* * *$} \\
\hline PI2 & 0.922 & & & & \\
\hline PI3 & 0.928 & & & & \\
\hline PI4 & 0.882 & & & & \\
\hline
\end{tabular}

Note: Sample size $(\mathrm{N})=400, \mathrm{CR}=$ Composite Reliability, AVE $=$ Average Variance Extracted, $\alpha=$ Cronbach's Alpha, $* * *$ p-value $<0.01, \mathrm{RE}=$ Recommendations, $\mathrm{OR}=$ Online Reviews, $\mathrm{PR}=$ Perceived Risk, AT $=$ Attitude, $\mathrm{SN}=$ Subjective Norm, PI = Purchase Intention 
Table 3. Inter-correlation (Discriminant validity test) for the Latent Variables

\begin{tabular}{lllllll}
\hline \hline Variables & RE & OR & PR & AT & SN & PI \\
\hline RE & $\mathbf{0 . 9 2 5}$ & & & & & \\
OR & 0.856 & $\mathbf{0 . 8 6 6}$ & & & & \\
PR & 0.656 & 0.681 & $\mathbf{0 . 8 8 0}$ & & & \\
AT & 0.762 & 0.825 & 0.662 & $\mathbf{0 . 9 0 6}$ & & \\
SN & 0.762 & 0.781 & 0.663 & 0.848 & $\mathbf{0 . 9 0 9}$ & $\mathbf{0 . 9 0 9}$ \\
PI & 0.763 & 0.792 & 0.623 & 0.801 & 0.843 & \\
\hline \hline
\end{tabular}

Note: Values in bold are square root of AVE, $\mathrm{RE}=$ Recommendations, $\mathrm{OR}=$ Online Reviews, $\mathrm{PR}=$ Perceived Risk, $\mathrm{AT}=$ Attitude, $\mathrm{SN}=$ Subjective Norm, $\mathrm{PI}=$ Purchase Intention To assess discriminant validity, we followed the criteria suggested by Fornell and Larcker (1981), and the results are presented in Table 3. With the Fornell and Larcker (1981) criteria, for the discriminant validity of each construct to be accepted, the average variance extracted square root should be greater than the highest correlation between the underlying construct and other constructs. As shown in Table 3, each construct's square root was greater than that of its correlation with other constructs affirming a good discriminant

\subsection{Structural Model Assessment}

The bootstrapping method was used to assess the tvalues and the significance of the path coefficients, and the indirect effect of the constructs to test the study's research hypothesis. This was done using a bootstrap re-sampling function embedded in the SmartPLS 3.2.9. The path coefficients or the original sample of the constructs have a standardized value ranging from -1 and +1 . The closer the estimated coefficients are geared towards 1 , the stronger the validity as recommended by (Fornell and Larcker, 1981).

Table 4. Path Coefficients of the Structural Model Constructs

\begin{tabular}{lllllll}
\hline $\begin{array}{l}\text { Constructs } \\
\text { Effects }\end{array}$ & OS & SM & STDEV & $\begin{array}{l}\text { T-Value } \\
(|\mathbf{O} / \mathbf{S T D E V}|)\end{array}$ & P-values & Conclusion \\
\hline RE - PI & 0.128 & 0.124 & 0.064 & 1.986 & $0.047^{* *}$ & Supported \\
RE - AT & 0.162 & 0.162 & 0.071 & 2.261 & $0.024^{* *}$ & Supported \\
RE - SN & 0.294 & 0.296 & 0.080 & 3.674 & $0.000^{* * *}$ & Supported \\
OR - PI & 0.200 & 0.210 & 0.080 & 2.489 & $0.013^{* * *}$ & Supported \\
OR - AT & 0.576 & 0.571 & 0.079 & 7.282 & $0.000^{* * *}$ & Supported \\
OR - SN & 0.391 & 0.387 & 0.093 & 4.217 & $0.000^{* * *}$ & Supported \\
PR - PI & -0.006 & 0.000 & 0.062 & 0.097 & 0.923 & Not Supported \\
PR - SN & 0.203 & 0.206 & 0.070 & 2.906 & $0.004^{* * *}$ & Supported \\
PR - AT & 0.163 & 0.168 & 0.067 & 2.439 & $0.015^{* *}$ & Supported \\
AT - PI & 0.139 & 0.143 & 0.096 & 1.449 & 0.148 & Not Supported \\
SN - PI & 0.475 & 0.460 & 0.112 & 4.244 & $0.000^{* * *}$ & Supported \\
\hline \hline
\end{tabular}

Note: $* * *$ p-value $<0.01, * *$ p-value $<0.05$, OS $=$ Original Sample $\mathrm{SM}=$ Sample Mean, STDEV $=$ Standard Deviation, $\mathrm{AT}=$ Attitude, $\mathrm{PI}=$ Purchase Intention, $\mathrm{OR}=$ Online Reviews, $\mathrm{PR}=$ Perceived Risk, $\mathrm{SN}=$ Subjective Norm, $\mathrm{RE}=$ Recommendations 
Table 4 presents the path coefficients for the direct relationship hypothesis. From the Table, nine out of the eleven hypotheses tested were supported. For example, online reviews (OR) has a significant influence on purchase intention (PI) as (OS $=0.200$, $\mathrm{t}$ value $=2.489$, and $p$-value $<0.05$ ). At the same time, perceived risk (PR) has a significant influence on attitude $(\mathrm{AT})$ as $(\mathrm{OS}=0.163, \mathrm{t}$ value $=2.439$, and $\mathrm{p}$ value $<0.05)$. Despite this, the perceived risk (PR) has an insignificant influence on purchase intention (PI) as $(\mathrm{OS}=-0.006, \mathrm{t}=$ value 0.097 , and $\mathrm{p}$-value $>$ 0.05). However, recommendations (RE) have a significant influence on purchase intention (PI) as $(\mathrm{OS}=0.128$, t value $=1.986$, and $\mathrm{p}$-value $<0.05)$.

This study also tested the mediation role of attitude and subjective norms in our research model, as shown in Table 5. The table revealed that three of the six hypotheses tested were supported, and the remaining three were not supported. For example, Attitude (AT) do not mediate the relationship between online review $(\mathrm{OR})$ and purchase intention $(\mathrm{PI})$ as $(\mathrm{OS}=0.080, \mathrm{t}$ value $=1.418$, and $\mathrm{p}$-value $>$ $0.05)$, as well as recommendations (RE) and purchase intention $(\mathrm{PI})$ as $(\mathrm{OS}=0.023, \mathrm{t}$ value $=$ 1.107 , and p-value $>0.05$ ). Despite this, Subjective Norm (SN) mediates the relationship between online review (OR) and purchase intention (PI) as $(\mathrm{OS}=$ $0.186, \mathrm{t}$ value $=3.447$, and $\mathrm{p}$-value $=0.101)$. Similarly, Subjective Norms (SN) mediates the relationship between recommendations (RE) and purchase intention $(\mathrm{PI})$ as $(\mathrm{OS}=0.140, \mathrm{t}$ value $=$ 2.542 , and $\mathrm{p}$-value $=0.011$ ).

Table 5. Decomposition of Indirect Effects of Constructs (Mediation Analysis)

\begin{tabular}{lcccccc}
\hline \hline Constructs Effects & $\ldots$, ST & SM & STDEV & T-Value $(|\mathbf{O} / \mathbf{S T D E V}|)$ & P-values & Conclusion \\
\hline RE - AT - PI & 0.023 & 0.024 & 0.020 & 1.107 & 0.268 & Not Supported \\
OR - AT - PI & 0.080 & 0.082 & 0.057 & 1.418 & 0.157 & Not Supported \\
PR - AT - PI & 0.023 & 0.023 & 0.019 & 1.170 & 0.242 & Not Supported \\
RE - SN - PI & 0.140 & 0.138 & 0.055 & 2.542 & $0.011^{* *}$ & Supported \\
OR - SN - PI & 0.186 & 0.175 & 0.054 & 3.447 & $0.001^{* * *}$ & Supported \\
PR - SN - PI & 0.096 & 0.094 & 0.039 & 2.440 & $0.015^{* *}$ & Supported \\
\hline \hline
\end{tabular}

Note: $* * *$ p-value $<0.01, * *$ p-value $<0.05, \mathrm{OS} / \beta=$ Original Sample/ Beta, $\mathrm{SM}=$ Sample Mean, STDEV $=\mathrm{Standard}$ Deviation, $\mathrm{AT}=$ Attitude, $\mathrm{PI}=$ Purchase Intention, $\mathrm{OR}=$ Online Reviews, $\mathrm{PR}=$ Perceived Risk, $\mathrm{SN}=\mathrm{Subjective} \mathrm{Norm}$, $\mathrm{RE}=$ Recommendations

\subsection{Discussion and Implications}

\subsection{Discussions of Findings}

This research proposes a conceptual framework to show how customer purchase intention can influence an online shopping platform among tertiary students in Ghana. Our findings revealed recommendations (RE) have a significant positive effect on purchase intention (PI), attitude (AT), and subjective norms (SN). Thus, tertiary students do buy products recommended by their friends. 
Simultaneously, their friend's recommendations can influence their online shopping attitude and how they react to the information received. The findings confirm previous studies done by Bai et al. (2015),
Di Maria and Finotto (2008), and Riemer and Lehrke (2009) that online consumers are likely to purchase a product recommended by their friends.

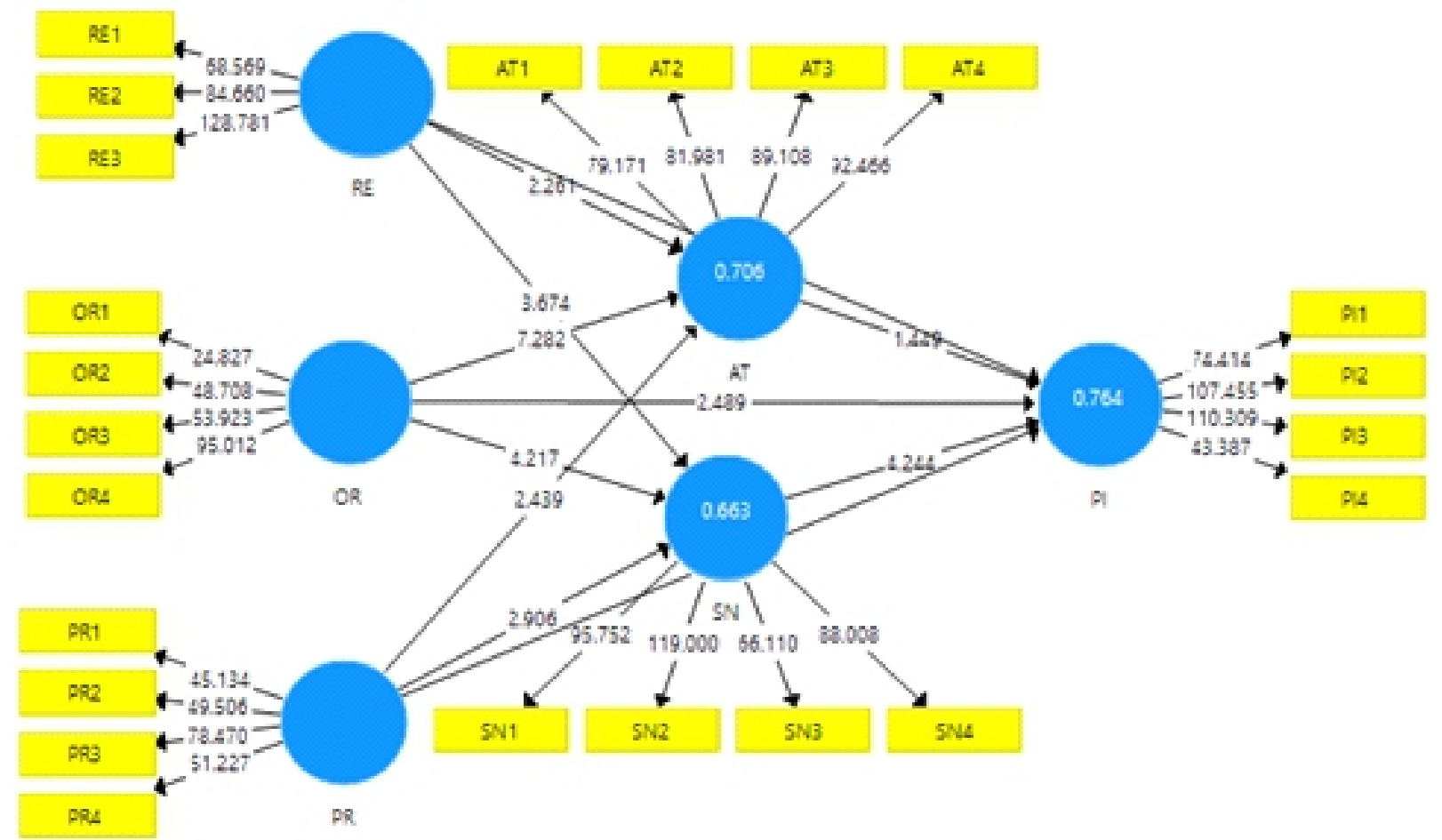

Figure1 : Structural Model

We also found a significant positive effect of online reviews (OR) on purchase intention (PI), attitude (AT), and subjective norm (SN). Thus, tertiary students are more concerned about their online shopping and, as such, may want more information, including product reviews, before deciding to purchase. Consequently, the product reviews left by early consumers influence their purchase intention as they rely on them. The research findings explain a relationship between online reviews and tertiary students' attitude to purchase and their subjective norms. Our results are similar to the work of Islam et al. (2017), who found out that consumers' information via online reviews helps them make a final purchasing decision. Also, the findings revealed that perceived risk (PR) has no effect on purchase intention (PI) but has a significant positive effect on subjective norms (SN) and attitude (AT). The findings suggest that tertiary students in Ghana would shop online regardless of the transaction risks. This could be attributed to a massive improvement by e-commerce platforms to ensure that online consumers have a pleasant shopping experience. The findings contradict early works (Rahman and Sloan 2017; Singh and Srivastava 2018).

Moreover, attitude (AT) was found not to influence purchase intention (PI), but subjective norms (SN) have a significant positive influence on purchase intention (PI). Thus, tertiary students in Ghana's attitude towards online shopping does not influence their purchase intention. The finding contradicts the earlier studies of Da Chen and Tan (2004); Lee et al. (2006); and Vijayasarathy (2004), who found a relationship between consumers' attitude towards online shopping their intention to purchase from an online shopping platform. On subjective norm, our finding confirms similar research done by (Al-Jabari et al. 2012; Jamil and Mat 2011, Leeraphong and 
Mardjo 2013).

Meanwhile, the current study found that attitude (AT) does not mediate the relationship between recommendations (RE), online reviews (OR), and perceived risk (PR) on purchase intention (PI). That is, their attitude towards online shopping does not cause the relationship between recommendations (RE), online reviews (OR), and perceived risk (PR) on tertiary students' intention to purchase. However, subjective norm (SN) positively mediates the relationship between recommendations (RE), online reviews (OR), and perceived risk (PR) on purchase intention (PI). The findings imply that their subjective norms cause the relationship between recommendations (RE), online reviews (OR), and perceived risk (PR) on purchase intention among tertiary students in Ghana.

\subsection{Theoretical Implications}

The current study elaborated on the determinants of online shopping among tertiary education students in Ghana, and it makes contributions to research in ecommerce. First, the study contributes to the existing literature on online shopping determinants in e-commerce by developing a conceptual model to explain the mechanism regarding purchase intention from the Ghanaian perspective. Most of the available literature on online shopping determinants was conducted in the advanced countries where ecommerce is predominant. This research adds up to the few works that have been done in Ghana. Through evaluating the mediation effects of attitude and subjective norms between recommendations, online reviews, and perceived risk on purchase intention among tertiary education students in Ghana, it is believed that this study would offer additional insights into online shopping as few studies have invested the moderating effects of attitude and subjective norms in an online shopping.

\subsection{Practical Implications}

The study provides several contributions to practice. First of all, the study findings suggest that recommendations can increase purchase intentions in an online shopping platform. At the same time, recommendations have a significant positive effect on attitudes and subjective norms. A student is likely to recommend a product or an online retailer to their fellow students if their past dealing was successful. Hence, online retailers must ensure that their customers have a good shopping experience. This can be done by attending to their questions on time, providing accurate product information, and others. Similarly, online reviews can influence purchase intention, attitude, and subjective norms.

Thus, the kind of feedback early consumers leave on their order is considered by new consumers. It can be deduced that a favorable online review will lead to a positive purchase intention among tertiary students in Ghana. Consequently, they should focus on designing marketing strategies to ensure their customers have a good shopping experience on their platforms. This may include encouraging early consumers to leave positive feedback and improvement of their service. Also, online retailers should deal with purchase reviews by customers on time and provide needed solutions, where necessary. Although perceived risk and attitude were found not to influence purchase intentions among tertiary education students in Ghana, online retailers need to maintain the kind of trust the online consumers have. Certain activities such as improvement in delivery or logistics system, payment system and effective customer service can help minimize risks associated with an online transaction.

\section{Limitations and Future Research}

This research involves some limitations that should be taken into consideration in future research. First, the respondents of our study were made up of only tertiary education students in Ghana. Hence, the findings may not be able to directly applicable to some other occupations within the country. Future studies should consider online consumers from diverse backgrounds. The study's scope is skewed to Ghana only; hence, this sample cannot be generalized as tertiary students' overall purchase 
intention in other geographical regions. Third, the variables used in our study were measured at a single point in time. Consequently, we suggest that future research should consider the longitudinal technique to confirm our findings.

Declaration: The authors declare no conflict of interest.

\section{References}

Ajzen, I. (1991). The theory of planned behavior. Organizational Behavior and Human Decision Processes, 50(2), 179-211. https://doi.org/10.1016/0749-5978(91)90020-T

Al-Jabari, M. A., Othman, S. N., Norezam Othman, S., Kamariah, N., \& Mat, N. (2012). Factors affecting work outcomes on the educators' continuous usage behaviour of Learning Management System (LMS): A proposed conceptual framework. American Journal of Economics, 125-129. https://doi.org/10.5923/j.economics.20120001.2 8

Amaro, S., \& Duarte, P. (2015). An integrative model of consumers' intentions to purchase travel online. Tourism Management, 46, 64-79. https://doi.org/10.1016/j.tourman.2014.06.006

Ansary, O. El. (2013). Factors Affecting Egyptian Consumers' Intentions for Accepting Online Shopping. The Journal of American Academy of Business, Cambridge, 19, 191-201. https://papers.ssrn.com/sol3/papers.cfm?abstrac $t$ id $=2856387$

Bai, Y., Yao, Z., \& Dou, Y. F. (2015). Effect of social commerce factors on user purchase behavior: An empirical investigation from renren.com. International Journal of Information Management, 35 (5), 538-550. https://doi.org/10.1016/j.ijinfomgt.2015.04.011

Bebber, S., Milan, G. S., De Toni, D., Eberle, L., \& Slongo, L. A. (2017). Antecedents of Purchase Intention in the Online Context. Journal of Relationship Marketing, 16 (1), $82-98$. https://doi.org/10.1080/15332667.2016.1242396

Bianchi, C., \& Andrews, L. (2012). Risk, trust, and consumer online purchasing behaviour: A Chilean perspective. International Marketing Review, 29 (3), $253-275$. https://doi.org/10.1108/02651331211229750

Business Insider. (2015). Why the weakening Ringgit is not all gloom and doom (Vol. 21). http://www. businessinsider. my/why-theweakening-ringgit-is-not-all-gloom-and-
doom/\#4boCLZDCior7Kkjo.97.

Chen, L. da, Gillenson, M. L., \& Sherrell, D. L. (2002). Enticing online consumers: An extended technology acceptance perspective. Information and Management, 39(8), 705-719. https://doi.org/10.1016/S0378-7206(01)00127-6

Chen, L. Da, \& Tan, J. (2004). Technology adaptation in E-commerce: Key determinants of virtual stores acceptance. European Management Journal, 22 ( 1 ), $74-86$. https://doi.org/10.1016/j.emj.2003.11.014

Chen, J., Xu, H., \& Whinston, A. B. (2011). Moderated online communities and quality of user-generated content. Journal of Management Information Systems, 28 (2), $237-268$. https://doi.org/10.2753/MIS0742-1222280209

Dai, B., Forsythe, S., \& Kwon, W. S. (2014). The impact of online shopping experience on risk perceptions and online purchase intentions: Does product category matter? Journal of Electronic Commerce Research, 15(1), 13-24. https://www.csulb.edu/journals/jecr/issues/2014 1/Paper2.pdf

DataReportal. (2020). Digital 2020 Global Digital Overview. In Hootsuite, We Are Social. https://datareportal.com/reports/digital-2020global-digital-overview

Davidson, A., \& Copulsky, J. (2006). Managing webmavens: Relationships with sophisticated customers via the Internet can transform marketing and speed innovation. Strategy and L e a d e rs hip, 34 ( 3), $14-22$. https://doi.org/10.1108/10878570610660564

Deneen, K., \& Yu, D. (2018). Online shopping is making many customers antagonistic. In Gallup. https://news.gallup.com/businessjour\%0Anal/18 $2006 /$ o nline - s hop ping-makingcustomersantagonistic.\%0Aaspx

Di Maria, E., \& Finotto, V. (2008). Communities of consumption and made in Italy. Industry and In novation, 15 (2), $179-197$. https://doi.org/10.1080/13662710801954583

Diallo, M. F., \& Siqueira, J. R. (2017). How previous positive experiences with store brands affect purchase intention in emerging countries: A comparison between Brazil and Colombia. International Marketing Review, 34(4), 536-558. https://doi.org/10.1108/IMR-07-2014-0224

Endert, J. (2018). Despite Ghana's commitment to Internet expansion, problems persist. https://www.dw.com/en/despite-ghanascommitment-to-internet-expansion-problemspersist/a-46508524

Engel, J. F., Blackwell, R. D., \& Miniard, P. W. (1995). 
Consumer Behavior (8th ed.). Dryden Press, Texas. https://www.worldcat.org/title/consumerbehavior/oclc/32666931

Fishbein, M., \& Ajzen, I. (1975). Belief, attitude, intention, and behavior: An introduction to theory and research. Addison-Wesley. https://people.umass.edu/aizen/f\&a1975.html

Fornell, C., \& Larcker, D. F. (1981). Evaluating Structural Equation Models with Unobservable Variables and Measurement Error. Journal of Marketing Research, 18(1), 39-50. https://doi.org/10.1177/002224378101800104

Forsythe, S., Liu, C., Shannon, D., \& Gardner, L. C. (2006). Development of a scale to measure the perceived benefits and risks of online shopping. Journal of Interactive Marketing, 20(2), 55-75. https://doi.org/10.1002/dir.20061

Gidey, A. (2017). Factors Affecting Online Repurchase Intention : Case Study of Ethiopian Airlines [St. Mary 's University]. http://repository.smuc.edu.et/handle/123456789/ 3566

Hair, J. F., Black, W. C., Babin, B. J., Anderson, R. E., \& Tatham, R. (2006). Multivariate Data Analysis. NJ: Pearson Prentice Hall. https://www.pearson.com/uk/educators/highereducation-educators/program/HairMultivariate-Data-Analysis-InternationalEdition-6th-Edition/PGM824389.html

Han, B., \& Windsor, J. (2011). User's willingness to pay on social network sites. Journal of Computer Information Systems, 51(4), 31-40. https://doi.org/10.1080/08874417.2011.1164549 9

Heinonen, K. (2011). Consumer activity in social media: Managerial approaches to consumers' social media behavior. Journal of Consumer Behaviour, 10(6), 356-364. https://doi.org/10.1002/cb.376

Islam, T., Wei, J., Sheikh, Z., Hameed, Z., \& Azam, R. I. (2017). Determinants of compulsive buying behavior among young adults: The mediating role of materialism. Journal of Adolescence, 61, $\begin{array}{lllllll}1 & 1 & 7 & - & 1 & 3 & 0\end{array}$. https://doi.org/10.1016/j.adolescence.2017.10.0 04

Jamil, N. A., \& Mat, N. K. N. (2011). To investigate the drivers of online purchasing behaviour in malaysia based on theory of planned behaviour (TPB): A structural equation modeling (SEM) Approach. In International Conference on Management (ICM 2011) Proceeding. Conference Master Resources, 443-460. https://www.econbiz.de/Record/investigatedrivers-online-purchasing-behaviour-malaysia- based-theory-planned-behaviour-structuralequation-modeling-approach-jamil-nordinabdul/10009205076

Jiménez-Castillo, D., \& Sánchez-Fernández, R. (2019). The role of digital influencers in brand recommendation: Examining their impact on engagement, expected value and purchase intention. International Journal of Information Ma $n$ a ge ment, 49, $366-376$. https://doi.org/10.1016/j.ijinfomgt.2019.07.009

Kashif, M., Zarkada, A., \& Ramayah, T. (2018). The impact of attitude, subjective norms, and perceived behavioural control on managers' intentions to behave ethically. Total Quality Management and Business Excellence, 29(5-6), $\begin{array}{lllllll}4 & 8 & 1 & - & 5 & 0 & 1\end{array}$. https://doi.org/10.1080/14783363.2016.1209970

Kelly, L., Kerr, G., \& Drennan, J. (2010). Avoidance of Advertising in Social Networking Sites. Journal of Interactive Advertising, 10(2), 16-27. https://doi.org/10.1080/15252019.2010.1072216 7

Kim, S., \& Park, H. (2013). Effects of various characteristics of social commerce (s-commerce) on consumers' trust and trust performance. International Journal of Information Management, 33 (2), $318-332$. https://doi.org/10.1016/j.ijinfomgt.2012.11.006

Kumar, D. V. (2018). Study on Trust \& Perceived Risk Regarding Online Shopping in Pune: A Factor Analysis. SSRN Electronic Journal, 2939(8), 1-9. https://doi.org/10.2139/ssrn.3049491

Lee, H. H., Fiore, A. M., \& Kim, J. (2006). The role of the technology acceptance model in explaining effects of image interactivity technology on consumer responses. International Journal of Retail and Distribution Management, 34(8), 621-644. https://doi.org/10.1108/09590550610675949

Lee, Y. N., Zailani, S., Rahman, M. K., Lee, Y. N., Zailani, S., \& Rahman, M. K. (2020). Determinants of Customer Intention to Purchase Social Enterprise Products : A Structural Model Analysis. Journal of Social Entrepreneurship, 1-22. https://doi.org/10.1080/19420676.2020.1718742

Leeraphong, A., \& Mardjo, A. (2013). Trust and Risk in Purchase Intention through Online Social Network: A Focus Group Study of Facebook in Thailand. Journal of Economics, Business and Ma nagement, 1 (4), 314-318. https://doi.org/10.7763/JOEBM.2013.V1.68

Liang, T. P., Ho, Y. T., Li, Y. W., \& Turban, E. (2011). What drives social commerce: The role of social support and relationship quality. International Journal of Electronic Commerce, 16(2), 69-90. 
https://doi.org/10.2753/JEC1086-4415160204

Lim, J. Y., Osman, A., Nizam, S., \& Rahim, A. (2016). Factors Influencing Online Shopping Behavior : The Mediating Role of Purchase Intention. Procedia Economics and Finance, 35(October 2015), 401-410. https://doi.org/10.1016/S22125671(16)00050-2

Malaquias, R. F., \& Hwang, Y. (2016). An empirical study on trust in mobile banking: A developing country perspective. Computers in Human Behavior, 54, $\begin{array}{lllllll}4 & 5 & 3 & - & 4 & 6 & 1\end{array}$. https://doi.org/10.1016/j.chb.2015.08.039

March, J. G. (1978). Bounded Rationality, Ambiguity, and the Engineering of Choice. The Bell Journal of Eco nomics, 9 (2), 587. https://doi.org/10.2307/3003600

Marsden, P. (2009). The 6 dimensions of social commerce: rated and reviewed. Social Commerce Today. www.digitalintelligencetoday.com/the-6dimensions-of-socialcommerce-rated-andreviewed

Mintah, S. C. (2018). Consumer Perceived Risk and Online Shopping in Ghana: The Moderating Role of Electronic-Word of Mouth [University of $\left.\begin{array}{llllll}G & h & a & n & a\end{array}\right]$ http://ugspace.ug.edu.gh/bitstream/handle/1234 56789/31162/Cusumer Perceived Risk and Online Shopping in Ghana -The Moderating Role of El e c t r o n i c - Word $o f$ Mouth.pdf? sequence $=1 \&$ is Allowed $=y$

Nunnally, J. C., \& Bernstein, I. H. (1994). Psychometric theory (3rd ed.). McGraw-Hill. https://www.worldcat.org/title/psychometrictheory/oclc/28221417

O'Cass, A., \& Fenech, T. (2003). Web retailing adoption: Exploring the nature of internet users Web retailing behaviour. Journal of Retailing and Consumer Services, 10(2), 81-94. https://doi.org/10.1016/S0969-6989(02)00004-8

Ofori, D., \& Appiah-Nimo, C. (2019). Determinants of online shopping among tertiary students in Ghana: An extended technology acceptance model. Cogent Business and Management, 6(1), $\begin{array}{llll}1 & - & 2 & 0\end{array}$ https://doi.org/10.1080/23311975.2019.1644715

Oghazi, P., Karlsson, S., Hellström, D., Mostaghel, R., \& Sattari, S. (2020). From Mars to Venus: Alteration of trust and reputation in online shopping. Journal of Innovation and Knowledge, 2-7. https://doi.org/10.1016/j.jik.2020.06.002

Olusoji, J. G., Olufemi, O., Jubril, L., \& Lucas, E. (2015). Risk and Trust in Online Shopping: Experience from Nigeria. International Journal of African and Asian Studies, 11(0), 71-77.
https://www.iiste.org/Journals/index.php/JAAS/a rticle/view/23937

Pavlou, P. A. (2003). Consumer acceptance of electronic commerce: Integrating trust and risk with the technology acceptance model. International Journal of Electronic Commerce, 7(3), 101-134. https://doi.org/10.1080/10864415.2003.1104427 5

Rahman, M. M., \& Sloan, T. (2017). User adoption of mobile commerce in Bangladesh: Integrating perceived risk, perceived cost and personal awareness with TAM. The International Technology Management Review, 6(3), 103. https://doi.org/10.2991/itmr.2017.6.3.4

Riemer, K., \& Lehrke, C. (2009). Biased listing in electronic marketplaces: Exploring its implications in online hotel distribution. International Journal of Electronic Commerce, 14(1), 55-78. https://doi.org/10.2753/JEC10864415140102

Sengretsi, S. (2020). Ecommerce in Ghana, 2020 - An Insightful Report. https://wopedigital.com/ecommerce-in-ghanal

Singh, N., Yadav, M., \& Sahu, O. (2016). Consumer acceptance of apparel e-commerce-Ethiopia. Intellectual Economics, 10(1), 55-62. https://doi.org/10.1016/j.intele.2016.06.001

Singh, S., \& Srivastava, S. (2018). Moderating effect of product type on online shopping behaviour and purchase intention: An Indian perspective. Cogent Arts \& Humanities, 5(1), 1-2 7. https://doi.org/10.1080/23311983.2018.1495043

Tamatompol, E., Pangemanan, S. S., \& Pandowo, M. (2017). A Qualitative Study Of Trust And Perceived Risk Of Online Shopping In Manado. Jurnal EMBA: Jurnal Riset Ekonomi, Manajemen, Bisnis Dan Akuntansi, 5(3), $\begin{array}{lllllllll}3 & 3 & 9 & 5 & - & 3 & 4 & 0 & 4\end{array}$. https://doi.org/10.35794/emba.v5i3.17516

Tevie, W., Quaynor, N. N., \& Bulley, A. (2016). Development of the Internet in Ghana. https://web.archive.org/web/20160103054130/ht tp://www.isoc.org/inet96/proceedings/g6/g6_4.ht $m$

Ventre, I., \& Kolbe, D. (2020). The Impact of Perceived Usefulness of Online Reviews, Trust and Perceived Risk on Online Purchase Intention in Emerging Markets: A Mexican Perspective. Journal of International Consumer Marketing, 32 (4), $287-299$. https://doi.org/10.1080/08961530.2020.1712293

Vijayasarathy, L. R. (2004). Predicting consumer intentions to use online shopping: The case for an augmented technology acceptance model., 
Information and Management, 41(6), 747-762. https://doi.org/10.1016/j.im.2003.08.011

Vlek, C., \& Stallen, P. J. (1980). Rational and personal aspects of risk. Acta Psychologica, 45(1-3) 273-300. https://doi.org/10.1016/00016918(80)90038-4

Wagner Mainardes, E., de Almeida, C. M., \& de-Oliveira, M. (2019).e-Commerce: an analysis of the factors that antecede purchase intentions in an emerging market. Journal of International Consumer Marketing, 31 (5), 447-468. https://doi.org/10.1080/08961530.2019.1605643

Wang, X., Pacho, F., Liu, J., \& Kajungiro, R. (2019). Factors influencing organic food purchase intention in Tanzania and Kenya and the moderating role of knowledge. Sustainability ( $S w i t z$ e r l a $n d$ ), $\quad 11$ (1). https://doi.org/10.3390/su11010209

Wang, Y., \& Hajli, N. (2015). Co-creating brand value through social commerce. In Handbook of Research on Integrating Social Media into Strategic Marketing (pp. 17-34). IGI Global. https://doi.org/10.4018/978-1-4666-83532.ch002

World Bank Report. (2018). Individuals using the Internet (\% of population) - Ghana. https://data.worldbank.org/indicator/IT.NET.US ER.ZS? locations $=G H$

Wu, P. C. S., Yeh, G. Y. Y., \& Hsiao, C. R. (2011). The effect of store image and service quality on brand image and purchase intention for private label brands. Australasian Marketing Journal, 19(1), 30-39. https://doi.org/10.1016/j.ausmj.2010.11.001

Xie, G., Zhu, J., Lu, Q., \& Xu, S. (2011). Influencing factors of consumer intention towards web group buying. IEEE International Conference on Industrial Engineering and Engineering Man a ge me $n t, 1397-1401$. https://doi.org/10.1109/IEEM.2011.6118146

Yakasai, A. B. M., \& Jusoh, W. J. W. (2015). Testing the Theory of Planned Behavior in Determining intention to use Digital Coupon among University Students. Procedia Economics and Finance, 31, 186-193. https://doi.org/10.1016/s22125671(15)01145-4 